\title{
YIELD AND QUALITY OF SUGAR BEET AS AFFECTED BY SOWING DATE, NITROGEN LEVEL AND FOLIAR SPRAYING WITH CALCIUM
}

\author{
H. E. A. Nemeata Alla \\ Sugar Crop Res. Ins., Agric. Res. Center, Giza
}

\begin{abstract}
Two field experiments were carried out at the Experimental Farm of Sakha Agric. Res. Station at the two successive growing seasons of $2013 / 2014$ and $2014 / 2015$ to study the effect of planting date, nitrogen level and foliar spraying with calcium on yield and quality of sugar beet. Split - split plot design was used in both seasons. Main plots contained the two sowing dates (on 20 September, 18 October 2013 in the first season and on 25 September, 29 October in the second season) and three nitrogen levels (80, 90 and $100 \mathrm{~kg} \mathrm{~N} / \mathrm{fad}$.) were arranged in sub-plot whereas, the two calcium rates $(0$ and $2 \mathrm{~g} / \mathrm{l}$.) were randomly distributed in sub- sub -plots. All treatments were replicated three replications. Important findings could be summarized as follows:

Resulted indicated that sowing sugar beet at early sowing date (on September) significantly increased root dimension, root/top ratio, top yield as well as root, sugar yields and extractability\%.

Application of nitrogen at the rate of $100 \mathrm{~N} / \mathrm{fad}$. significantly increased both root dimension, top, root and sugar yields. On the other hand, increasing $\mathrm{N}$ rate up to $100 \mathrm{~kg} \mathrm{~N} / \mathrm{fad}$. tended to decrease both root/top ratio, purity\%, TSS\% as well as sucrose and sugar losses in molas percentages.

Foliar spraying with calcium significantly affected root dimensions, top, root and sugar yields as well as extractability\% and TSS\%.
\end{abstract}

\section{INTRODUCTION}

Sugar beet crop (Beta vulgaris, L.) considered the important source for sugar after sugar cane in Egypt as well as in the world. Many of cultural practices such as sowing date, nitrogen fertilizer are very important factors, which limiting sugar production from sugar beet in addition to spraying with calcium element, which have important role in plant physiology and cell structure.

Sowing date at suitable time is very important to obtained higher yield and quality as sowing on September under Egyptian conditions. Srivastava and Singh (1981); Hanna et al. (1988) and Nemeat Alla (2007) concluded that planting sugar beet on October surprising than planting on other dates in most sugar beet characters i.e., root weight, root yield and sugar yield.

Nitrogen fertilizer rate playing an limiting factor for sugar production of sugar beet. Increasing nitrogen rate had a reflection effect or inversion effect on quality characters as, sucrose and purity 
as well as extractability\% and total soluble solids \%, Lalia et al. (2005). Whereas, increasing nitrogen rate tended to increase top, root, sugar yields, Sadre et al. (2012), Salim et al (2012), Gomea et al. (2013) and EL-Sarag and Moselhy (2013) found that increasing nitrogen rate increased root, top and sugar yields. While it decreased sugar beet quality in the same time.

Application of calcium element to sugar beet as foliar spraying with enough amount had significant effect on top yield, root yield and sugar yield. Biaczyk (2005) and Artysza et al. (2014) reported that Calcium significantly increased root yield by $13.1 \%$ and top yield by about $21 \%$ and biological sugar yield by about $15.5 \%$.

This study was aimed to limited the optimum sowing date and the optimum rate of nitrogen with suitable calcium dose as foliar application to obtained maximum sugar beet yield and quality under the conditions. of Kafer EL-Sheikh Governorate.

\section{MATERIALS AND METHODS}

Two series of field experiments were conducted at the Experimental Farm of Sakha Agric. Res. Station during two successive seasons, 2013/2014 and 2014/2015. The preceding crop was corn in the two seasons. Chemical analysis of experimental soils in the two seasons are presented in Table (1).

Table (1): Chemical analysis of soil experimental site (0-30 cm in depth) of the

Experimental Farm of Sakha Agric. Research Station in (2013/2014 and 2014/2015) seasons

\begin{tabular}{|c|c|c|c|c|c|c|c|c|c|c|}
\hline \multirow{2}{*}{ Season } & \multirow{2}{*}{$\begin{array}{c}\mathrm{PH} \\
1: 2.5\end{array}$} & \multirow{2}{*}{$\mathrm{EC} / \mathrm{m}$} & \multirow{2}{*}{$\begin{array}{c}\text { Organic } \\
\text { matter\% }\end{array}$} & $\begin{array}{c}\mathrm{N} \\
\mathrm{ppm}\end{array}$ & $\begin{array}{c}\mathrm{P} \\
\mathrm{ppm}\end{array}$ & $\begin{array}{c}\mathrm{K} \\
\mathrm{ppm}\end{array}$ & $\mathrm{HCO}_{3-}{ }^{-}$ & $\mathrm{Cl}$ & $\mathrm{SO}_{4}{ }^{-}$ & $\mathrm{CO}_{3^{-}}$ \\
\hline $2013 / 2104$ & 8.3 & 3.42 & 1.85 & 16.14 & 6.22 & 288.11 & 6.2 & 5.6 & 0.15 & 0.0 \\
\hline $2014 / 2015$ & 8.5 & 3.38 & 1.78 & 15.76 & 6.31 & 282.25 & 6.5 & 6.2 & 0.19 & 0.0 \\
\hline
\end{tabular}

The experimental soils was fertilized with $24 \mathrm{~kg} \mathrm{~K}_{2} \mathrm{O} /$ fad in form of potassium sulphate $\left(48 \% \mathrm{~K}_{2} \mathrm{O}\right)$ during land preparation.

A split - split plot design with three replications was used. The main plots were assigned by the two sowing dates ( September and October) and the sub plots contained nitrogen levels, (80, 90 and 100 $\mathrm{kg} \mathrm{N} / \mathrm{fad}$.), while calcium fertilizer as foliar application was randomly distrusted in the sub sub plots in both seasons.

Each sub-sub plot included six ridges $55 \mathrm{~cm}$ apart and $7 \mathrm{~m}$. long. Sowing took place on 20 September, 18 October 2013 in the first season and on 25 September, 29 October in the second season.

Seed of multigerm cultivar "Byramide " was sown in hills $20 \mathrm{~cm}$ apart at rate of 3-4 seeds per hill. Plants were thinned to one plant per 
hill at four true leaves stage. Nitrogen fertilizer in from of Urea $(46 \% N)$ with mentioned rates were added in two equal doses. The first one was applied after thinning and the other one after one month later. Solution of calcium sulphate at the rate of $(2 \mathrm{~g} / \mathrm{l})$ and distilled water were sprayed after 65 days from sowing. The other cultural practices were done as recommended.

At maturity (205 days from sowing), the area of four guarded ridges were harvested to determine top and root yields, as well as quality of beets. Sample of ten guarded plants were taken at random to estimate root dimension (length and diameter). Concerning the quality as total soluble solids (T.S.S) percentage was determined with hand refractometer, sucrose percentage was determined using the method described by Le Docte (1927) and Mc Ginnus (1971).

Non soluble sugar in term of impurities ( $\mathrm{K}$ and $\mathrm{Na}$ element ) were determined using flame photometer according to Brown and Lilliand (1964) and $\alpha$ - amino $N$ was determined using ninhydrin and hydrindantin method according to Carruthers et al. (1962).

- Purity percentage $=99.36-\{14.27(\mathrm{v} 1+\mathrm{v} 2+\mathrm{v} 3 / \mathrm{v} 4)$.

Where:

$$
\begin{array}{cl}
\mathrm{V}_{1}=\text { Sodium \% } & \mathrm{V}_{2}=\text { Potassium \% } \\
\mathrm{V}_{3}=\alpha-\text { amino } \mathrm{N} \% & \mathrm{~V}_{4}=\text { Sucrose } \%(\text { Pol } \%)
\end{array}
$$

- Sugar losses to molasses $(\mathrm{SM})=(\mathrm{v} 1+\mathrm{v} 2) 0.14+\mathrm{v} 3 \times 0.25+0.5$ Deviller (1988).

- Extractable sugar \% = v4 - SM - 0.6 Dexter et al. (1967).

- Extractability \% = Extractable / sucrose \%.

- Alkalinity coefficient $=\mathrm{v} 1+\mathrm{v} 2 / \mathrm{v} 3$ Harvey and Dutton (1993).

- Sugar yield $($ ton/fad. $)=$ root yield $\times$ sucrose $\% \times$ purity $\%$.

The analysis of variance was carried out according to Gomez and Gomez (1984). Treatment means were compeered by Duncan's maltiple range test (Duncan, 1955). All statistical analysis were performed using analysis of variance technique by means of "Cohort" computer software package.

\section{Root dimensions:}

\section{RESULTS AND DISCUSSION}

Root dimensions (length and diameter) as affected by sowing date, nitrogen rate and foliar spraying with calcium in 2013/2014 and 2014/2015 seasons are presented in Table (2).

Sowing date significantly affected root length and root diameter in both seasons, Table (2). First sowing date increased root dimensions (length and diameters) compared with second sowing. Similar results were obtained by Mahmoud et al.(1999), EL - Kassaby and Leilah (1992) and Bassal et al.(2001). 
Nitrogen fertilizer level had a significant effect on root dimensions (length and diameter) at harvest in both seasons. The highest values of root length and diameter were recorded at $100 \mathrm{~kg} \mathrm{~N} / \mathrm{fad}$. These results are in agreement with those of Abd EL - Hadi et al.(2002), Ismail and Ghait (2005) and Nemeat Alla et al. (2014).

The obtained results showed clearly that dimension was increased with spraying of calcium in both seasons. The highest values of root length 33.04 and $33.11 \mathrm{~cm}$ as well as root diameter 9.77 and $10.67 \mathrm{~cm}$. Were recorded with plants sprayed with calcium at $2 \mathrm{~g} / \mathrm{l}$. in 2013/2014 and 2014/2015 seasons, respectively. The increase in root dimensions due to spraying with calcium may be attributed to increasing in cell number and size. These results are in harmony with those obtained Nemeat Alla (2009).

Table (2): Root length $(\mathrm{cm})$, root diameter $(\mathrm{cm})$ and root/top ratio as affected by sowing date, nitrogen rate and foliar application of calcium in 2013/2014 and 2014/2015 seasons

\begin{tabular}{|c|c|c|c|c|c|c|}
\hline \multirow{3}{*}{ Factor } & \multicolumn{2}{|c|}{ Root length (cm) } & \multicolumn{2}{|c|}{ Root diameter (cm) } & \multicolumn{2}{|c|}{ Root/Top ratio\% } \\
\hline & \multicolumn{6}{|c|}{ seasons } \\
\hline & $2013 / 14$ & $2014 / 15$ & $2013 / 14$ & $2014 / 15$ & $2013 / 14$ & $2014 / 15$ \\
\hline \multicolumn{7}{|c|}{ Sowing date (S): } \\
\hline First date & $43.12 a$ & $33.95 a$ & $10.42 \mathrm{a}$ & $11.46 a$ & $3.11 \mathrm{~b}$ & $2.93 \mathrm{~b}$ \\
\hline $\begin{array}{l}\text { Second } \\
\text { date }\end{array}$ & $31.44 b$ & $31.76 b$ & $8.81 b$ & $9.47 b$ & $3.75 a$ & $3.61 \mathrm{a}$ \\
\hline F- test & ** & ** & ** & ** & ** & ** \\
\hline \multicolumn{7}{|c|}{$\mathrm{N}$ - Fertilizer rate (kg N/fad.) $(\mathrm{N})$ : } \\
\hline 80 & $31.71 \mathrm{c}$ & $32.04 \mathrm{c}$ & $9.08 \mathrm{c}$ & $9.71 c$ & $3.51 \mathrm{a}$ & $3.39 a$ \\
\hline 90 & $32.58 \mathrm{~b}$ & $32.81 b$ & $9.58 b$ & $10.48 \mathrm{~b}$ & $3.47 b$ & $3.31 b$ \\
\hline 100 & $34.05 a$ & $33.71 \mathrm{a}$ & $10.19 a$ & $11.21 \mathrm{a}$ & $3.30 c$ & $3.10 c$ \\
\hline F- test & ** & ** & ** & ** & ** & ** \\
\hline \multicolumn{7}{|c|}{ Foliar app. of calcium $(2 g / l)(F)$ : } \\
\hline 0 & $32.52 b$ & $32.59 \mathrm{~b}$ & $9.46 \mathrm{~b}$ & $10.26 \mathrm{~b}$ & 3.43 & 3.29 \\
\hline 2 & $33.04 a$ & $33.11 \mathrm{a}$ & $9.77 a$ & $10.67 a$ & 3.42 & 3.25 \\
\hline F- test & ** & ** & ** & ** & NS & NS \\
\hline \multicolumn{7}{|c|}{ Interaction: } \\
\hline $\mathrm{S} \times \mathrm{N}$ & ** & ** & NS & ** & ** & ** \\
\hline $\mathrm{S} \times \mathrm{F}$ & NS & ** & NS & ** & * & NS \\
\hline $\mathrm{N} \times \mathrm{F}$ & NS & NS & NS & NS & * & NS \\
\hline $\mathrm{S} \times \mathrm{N} \times \mathrm{F}$ & ** & * & NS & NS & NS & NS \\
\hline
\end{tabular}

${ }^{*}$ and N.S indicated $\mathrm{P}<0.05$ and not significant, respectively. Means within the same column for each factor designed by the same letter are not significantly different at $5 \%$ level according to Duncan's multiple range test.

Data presented in Table (2-a1) show that early sowing gave the highest root length $(35.90$ and $36.07 \mathrm{~cm}$.) when sugar beet plants fertilized with maximum $\mathrm{N}$ rate $100 \mathrm{~kg} \mathrm{~N} / \mathrm{fad}$. in both seasons. 
Table (2-a1): Root length (cm) as affected by the interaction between sowing date and nitrogen rate in 2013/2014 and 2014/2015 seasons

\begin{tabular}{|c|c|c|c|}
\hline \multirow{2}{*}{ Sowing date } & \multicolumn{3}{|c|}{ N. rate (kg N/ fad.) } \\
\cline { 2 - 4 } & 80 & 90 & 100 \\
\hline \multicolumn{4}{|c|}{$2013 / 2014$} \\
\hline First date & $32.80 \mathrm{c}$ & $33.65 \mathrm{~b}$ & $35.90 \mathrm{a}$ \\
\hline Second date & $30.62 \mathrm{f}$ & $31.50 \mathrm{e}$ & $32.20 \mathrm{~d}$ \\
\hline \multicolumn{4}{|c|}{$2014 / 2015$} \\
\hline First date & $32.99 \mathrm{c}$ & $33.80 \mathrm{~b}$ & $36.07 \mathrm{a}$ \\
\hline Second date & $31.10 \mathrm{f}$ & $31.82 \mathrm{e}$ & $32.35 \mathrm{~d}$ \\
\hline
\end{tabular}

Means designed by the same letter are not significantly different at $5 \%$ level, using Duncan's multiple range test.

As for the second order, the interaction among sowing date $x$ nitrogen rate $\times$ foliar application of calcium data in Table (2-a2) pointed out that sowing sugar beet plants at early sowing date (September) and fertilized with $100 \mathrm{~kg} \mathrm{~N} / \mathrm{fad}$ under foliar application of calcium at rate of $(2 \mathrm{~g} / \mathrm{l})$ produced the highest root length in both seasons.

Table (2-a2): Root length $(\mathrm{cm})$ as affected by the interaction among sowing date, N-rate and foliar application of calcium in 2103/2014 and 2014/2015 seasons

\begin{tabular}{|c|c|c|c|c|}
\hline \multirow{2}{*}{ Sowing date } & $\begin{array}{c}\text { Foliar of } \\
\text { calcium (2g/l) }\end{array}$ & \multicolumn{3}{|c|}{ N. rate (kg N / fad.) } \\
\cline { 3 - 5 } & & 80 & 90 & 100 \\
\hline \multicolumn{5}{|c|}{$2013 / 2014$} \\
\hline \multirow{2}{*}{ First date } & 0 & $32.60 f$ & $33.40 \mathrm{~d}$ & $35.47 \mathrm{~b}$ \\
\cline { 2 - 5 } & 2 & $33.00 \mathrm{e}$ & $33.90 \mathrm{c}$ & $36.33 \mathrm{a}$ \\
\hline \multirow{2}{*}{ Second date } & 0 & $30.30 \mathrm{l}$ & $31.27 \mathrm{j}$ & $32.07 \mathrm{~h}$ \\
\cline { 2 - 5 } & 2 & $30.93 \mathrm{k}$ & $31.73 \mathrm{i}$ & $32.33 \mathrm{~g}$ \\
\hline \multirow{2}{*}{ First date } & 0 & $3214 / 2015$ & $33.53 \mathrm{~d}$ & $34.60 \mathrm{~b}$ \\
\cline { 2 - 5 } & 2 & $33.20 \mathrm{e}$ & $34.07 \mathrm{c}$ & $35.53 \mathrm{a}$ \\
\hline \multirow{2}{*}{ Second date } & 0 & $30.80 \mathrm{f}$ & $31.70 \mathrm{j}$ & $32.17 \mathrm{~h}$ \\
\cline { 2 - 5 } & 2 & $31.40 \mathrm{k}$ & $31.93 \mathrm{i}$ & $32.53 \mathrm{~g}$ \\
\hline
\end{tabular}

Means designed by the same letter are not significantly different at $5 \%$ level, using Duncan's multiple range test.

\section{Root/top ratio:}

Root/top ratio considered as indicator to optimum time for harvest of sugar beet. Data tabulated in Table (2) presented the effect of sowing date, nitrogen level and foliar application of calcium on root/top ratio.

Results in this Table showed that planting date had a significant effect in the only second season. Planting sugar beet at early date gave a good chance to increase top growth rate than root and gave lowest values compared to postponing sowing, which gave chance to root to increase in growth rate than top and gave the highest 
root/top ratio . These results were in agreement with those obtained by Leilah et al. (2005).

As effect of nitrogen level on this trait, data in Table (2) show a significant effect on root/top ratio only in the second season. Increasing $\mathrm{N}$-level gradually decreased root/top ratio in the second season. In the first season, increasing $\mathrm{N}$ - level tended to decrease root/top ratio but the differences did not reach the $5 \%$ level of significant. Similar results were found by Nemeat Alla et al. (2007) and Nemeat Alla (2009).

As respect to effect of calcium application as foliar on root/top ratio, data in Table (2) pointed out that spraying with calcium at rate of $2 \mathrm{~g} / \mathrm{l}$. exhibited no significant effect on both seasons. These results coincided with those stated by Nemeat Alla (2009).

The interaction effect between sowing date $\times \mathrm{N}$ rate was significant in both seasons Table (2-a3). Maximum ratio for root/top was found when sugar beet was sowing early on 20 September in 2103 and on 25 September in 2104 and fertilized with $100 \mathrm{~kg} \mathrm{~N} / \mathrm{fad}$. This was true in both seasons.

Table (2-a3): Root/top ratio as affected by the interaction between sowing date and nitrogen rate in 2013/2014 and 2014/2015seasons

\begin{tabular}{|c|c|c|c|}
\hline \multirow{2}{*}{ Sowing date } & \multicolumn{3}{|c|}{ N. rate (kg N/ fad.) } \\
\cline { 2 - 4 } & 80 & 90 & 100 \\
\hline \multicolumn{4}{|c|}{$2013 / 2014$} \\
\hline First date & $3.14 \mathrm{~d}$ & $3.11 \mathrm{de}$ & $3.07 \mathrm{e}$ \\
\hline Second date & $3.88 \mathrm{a}$ & $3.83 \mathrm{~b}$ & $3.53 \mathrm{c}$ \\
\hline \multicolumn{4}{|c|}{$2014 / 2015$} \\
\hline First date & $3.12 \mathrm{c}$ & $2.93 \mathrm{~d}$ & $2.75 \mathrm{e}$ \\
\hline Second date & $3.70 \mathrm{a}$ & $3.67 \mathrm{a}$ & $3.46 \mathrm{~b}$ \\
\hline
\end{tabular}

Means designed by the same letter are not significantly different at $5 \%$ level, using Duncan's multiple range test.

Top, root and sugar yields (t/fad.):

The final goal for sugar beet cultivate is the highest values of top, root and sugar yields. Data in Table (3) showed clearly that sowing date had a significant affect on these three traits in both seasons. Planting sugar beet at early sowing date (on 20 September in 2103 and on 25 September in 2104) gave the highest values in both seasons (8.89, 8.81, 27.60, 25.88 and 5.13, $4.92 \mathrm{t} / \mathrm{fad}$.) from top, root and sugar yields/fad., respectively. 
Table (3): Top, Root yield and sugar yields (t/fad.) as affected by sowing date, nitrogen rate and foliar application of calcium in 2013/2014 and 2014/2015 seasons

\begin{tabular}{|c|c|c|c|c|c|c|}
\hline \multirow{3}{*}{ Factor } & \multicolumn{2}{|c|}{ Top yield (t/fad.) } & \multicolumn{2}{|c|}{ Root yield (t/fad.) } & \multicolumn{2}{|c|}{ sugar yield (t/fad.) } \\
\hline & \multicolumn{6}{|c|}{ seasons } \\
\hline & $2013 / 14$ & $2014 / 15$ & $2013 / 14$ & $2014 / 15$ & $2013 / 14$ & $2014 / 15$ \\
\hline \multicolumn{7}{|c|}{ Sowing date $(\mathrm{S})$ : } \\
\hline First date & $8.89 a$ & $8.81 \mathrm{a}$ & $27.60 \mathrm{a}$ & $25.88 \mathrm{a}$ & $5.13 a$ & $4.92 \mathrm{a}$ \\
\hline $\begin{array}{l}\text { Second } \\
\text { date }\end{array}$ & $6.39 b$ & $6.95 b$ & $23.84 b$ & $22.98 b$ & $4.47 b$ & $4.39 b$ \\
\hline F- test & ** & ** & ** & ** & ** & ** \\
\hline \multicolumn{7}{|c|}{$\mathrm{N}$-Fertilizer rate (kg N/fad.) (N): } \\
\hline 80 & $6.71 \mathrm{c}$ & $6.64 \mathrm{c}$ & $23.17 \mathrm{c}$ & $22.49 c$ & $4.60 \mathrm{c}$ & $4.50 \mathrm{c}$ \\
\hline 90 & $7.49 b$ & $8.00 \mathrm{~b}$ & $25.51 \mathrm{~b}$ & $24.28 b$ & $4.80 \mathrm{~b}$ & $4.64 b$ \\
\hline 100 & $8.73 a$ & $8.81 \mathrm{a}$ & $28.48 \mathrm{a}$ & $26.54 a$ & $4.90 \mathrm{a}$ & $4.82 \mathrm{a}$ \\
\hline F- test & ** & ** & ** & ** & ** & ** \\
\hline \multicolumn{7}{|c|}{ Foliar app. of calcium $(2 \mathrm{~g} / \mathrm{l})(\mathrm{F})$ : } \\
\hline 0 & $7.50 \mathrm{~b}$ & $7.71 \mathrm{~b}$ & $25.21 b$ & $24.08 \mathrm{~b}$ & $4.76 \mathrm{~b}$ & $4.63 \mathrm{~b}$ \\
\hline 2 & $7.79 a$ & $8.06 a$ & $26.23 a$ & $24.79 a$ & $4.83 a$ & $4.68 a$ \\
\hline F- test & ** & ** & ** & ** & ** & * \\
\hline \multicolumn{7}{|c|}{ Interaction: } \\
\hline $\mathrm{S} \times \mathrm{N}$ & ** & ** & ** & NS & ** & ** \\
\hline $\mathrm{S} \times \mathrm{F}$ & NS & NS & ** & NS & ** & NS \\
\hline $\mathrm{N} \times \mathrm{F}$ & NS & NS & ** & NS & NS & NS \\
\hline $\mathrm{S} \times \mathrm{N} \times \mathrm{F}$ & ** & * & ** & NS & * & NS \\
\hline
\end{tabular}

${ }^{*}$ and N.S indicated $\mathrm{P}<0.05$ and not significant, respectively. Means within the same column for each factor designed by the same letter are not significantly different at $5 \%$ level according to Duncan's multiple range test.

These observations were accordance with those found by Srivastava and Singh (1981), Hanna et al. (1988), Kandil et al (2002), Leilah et al (2005) and Refay (2010).

Regarding to effect of nitrogen rate on top, root and sugar yields, data presented in Table (3) pointed out that all of these mentioned traits (top, root and sugar yields) were significantly increased with increasing nitrogen rate from 80 to $100 \mathrm{~kg} \mathrm{~N} / \mathrm{fad}$. Each increment of nitrogen fertilizer resulted in a significant increase in top, root and sugar yields. This fact was true in both seasons. These significant increases among mean values of these traits may be due to physiological role of nitrogen in increasing photosynthesis rate and crop growth rate by increasing cell size ( elongate and number ) for root and top of beet plants, which reflected on higher increase in yields of top, root and sugar in both seasons. These results are in harmony with those obtained by Kandil et al. (2002), Leilah et al. (2005), ElSarag and Moselhy (2013), and Gomaa et al. (2013). 
As for the effect of foliar application of calcium on top, root and sugar yields of sugar beet, significant differences were observed between mean values in both seasons, Table (3). Application of calcium element to sugar beet as foliar at the rate of $2 \mathrm{~g} / \mathrm{l}$. gave maximum yields of top, root and sugar in both seasons. These advantage resulted from application of calcium to sugar beet may be due to his important role in normal photosynthesis activity of sugar beet leaves, which caused in sugar beet healthy roots. Similar results were found by Biaczyk (2005), Nemeat Alla (2009) and Artyszak et al. (2014). The interaction effects between sowing date $\times$ nitrogen rate on top yield showed significant effects on top yield in both seasons as shown in Table (3-a1). The highest values of top yields were obtained from early sowing under $100 \mathrm{~kg} \mathrm{~N} / \mathrm{fad}$ in both seasons.

Table (3-a1): Top yield (t/fad.) as affected by the interaction between sowing date and nitrogen rate in 2013/2014 and 2014/2015 seasons

\begin{tabular}{|c|c|c|c|}
\hline \multirow{2}{*}{ Sowing date } & \multicolumn{3}{|c|}{ N- rate (kg N/fad.) } \\
\cline { 2 - 4 } & 80 & 90 & 100 \\
\hline \multicolumn{4}{|c|}{$2013 / 2014$} \\
\hline First date & $7.67 \mathrm{c}$ & $8.79 \mathrm{~b}$ & $10.21 \mathrm{a}$ \\
\hline Second date & $5.74 \mathrm{f}$ & $6.19 \mathrm{e}$ & $7.25 \mathrm{~d}$ \\
\hline \multicolumn{4}{|c|}{$2014 / 2015$} \\
\hline First date & $4.48 \mathrm{~d}$ & $9.23 \mathrm{~b}$ & $9.73 \mathrm{a}$ \\
\hline Second date & $6.19 \mathrm{f}$ & $6.78 \mathrm{e}$ & $7.89 \mathrm{c}$ \\
\hline
\end{tabular}

Means designed by the same letter are not significantly different at $5 \%$ level, using Duncan's multiple range test.

Significant interaction effects were found on top yield/fad. resulted from the interaction among the three factors under study, Table (3-a2).

Table (3-a2): Top yield (t/fad.) as affected by the interaction among sowing date, foliar application of calcium and nitrogen rate in 2103/2014 and 2014/2015 seasons

\begin{tabular}{|c|c|c|c|c|}
\hline \multirow{2}{*}{ Sowing date } & $\begin{array}{c}\text { Foliar of } \\
\text { calcium (2g/l) }\end{array}$ & \multicolumn{3}{|c|}{ N-rate (kg N / fad.) } \\
\cline { 3 - 5 } & \multicolumn{5}{|c|}{$2013 / 2014$} \\
\hline \multirow{2}{*}{ First date } & 0 & $7.56 \mathrm{f}$ & $8.58 \mathrm{~d}$ & 100 \\
\cline { 2 - 5 } & 2 & $7.78 \mathrm{e}$ & $8.99 \mathrm{c}$ & $10.02 \mathrm{~b}$ \\
\hline \multirow{2}{*}{ Second date } & 0 & $5.57 \mathrm{l}$ & $6.08 \mathrm{j}$ & $7.16 \mathrm{~h}$ \\
\cline { 2 - 5 } & 2 & $5.91 \mathrm{k}$ & $6.29 \mathrm{i}$ & $7.33 \mathrm{~g}$ \\
\hline \multirow{2}{*}{ First date } & 0 & $2014 / 2015$ & & $9.63 \mathrm{a}$ \\
\cline { 2 - 5 } & 2 & $7.17 \mathrm{f}$ & $9.09 \mathrm{c}$ & $9.83 \mathrm{a}$ \\
\hline \multirow{2}{*}{ Second date } & 0 & $7.79 \mathrm{e}$ & $9.36 \mathrm{~b}$ & $7.75 \mathrm{e}$ \\
\cline { 2 - 5 } & 2 & $6.06 \mathrm{i}$ & $6.55 \mathrm{~g}$ & $8.04 \mathrm{~d}$ \\
\hline
\end{tabular}


Means designed by the same letter are not significantly different at $5 \%$ level, using Duncan's multiple range test.

Data show that sowing sugar beet at early date and fertilized with $100 \mathrm{~kg} \mathrm{~N} / \mathrm{fad}$. under application of calcium at the rate of $2 \mathrm{~g} / \mathrm{l}$. recorded the highest values of top yield (10.41 and $9.83 \mathrm{t} / \mathrm{fad}$.

Significant interaction effects were found in both seasons on sugar yield/fad., which resulted from combination between sowing date $x$ nitrogen level. Table (3-a3). Maximum sugar yield /fad. was obtained (5.48 and $5.08 \mathrm{t} /$ fad.) from the interaction between early sowing date and $100 \mathrm{~kg} \mathrm{~N} / \mathrm{fad}$.

Table (3-a3): Sugar yield (t/fad.) as affected by the interaction between sowing date and nitrogen rate in 2013/2014 and 2014/2015 seasons

\begin{tabular}{|c|c|c|c|}
\hline \multirow{2}{*}{ Sowing date } & 80 & 90 & 100 \\
\hline \multicolumn{4}{|c|}{$\mathrm{N}$ - rate (kg N / fad.) } \\
\hline First date & $4.81 \mathrm{c}$ & $5.09 \mathrm{~b}$ & $5.48 \mathrm{a}$ \\
\hline Second date & $4.02 \mathrm{e}$ & $4.50 \mathrm{~d}$ & $4.50 \mathrm{~d}$ \\
\hline \multicolumn{4}{|c|}{$2014 / 2015$} \\
\hline First date & $4.81 \mathrm{c}$ & $4.87 \mathrm{~b}$ & $5.08 \mathrm{a}$ \\
\hline Second date & $4.20 \mathrm{f}$ & $4.31 \mathrm{e}$ & $4.56 \mathrm{~d}$ \\
\hline
\end{tabular}

Means designed by the same letter are not significantly different at $5 \%$ level, using Duncan's multiple range test.

\section{Impurities ( $\mathrm{Na}, \mathrm{K}$ and $\alpha$ amino $\mathrm{N}$ ) soluble non sugar (meq/100g beet):}

Containing sugar beet root low impurities values is very important to obtained good quality from sugar beet. So, this investigation tried to reduce these values to improve sugar beet root quality. The present data in Table (4) show that sowing date had no significant effect on impurities values ( $\mathrm{Na}, \mathrm{K}$ and $\alpha$ amino $\mathrm{N}$ ) in both seasons, except that $\mathrm{K}$ - content in the second season.

Concerning the effect of nitrogen fertilizer level on impurities ( $\mathrm{Na}, \mathrm{K}$ and $\alpha$-amino nitrogen), highly significant differences were observed among values of impurities in both seasons, Table (4). 
Table (4): $\mathrm{Na}, \mathrm{K}$ and $\mathrm{\alpha}-\mathrm{N}$ as affected by sowing date, nitrogen rate and foliar application of calcium in 2013/2014 and 2014/2015 seasons

\begin{tabular}{|c|c|c|c|c|c|c|}
\hline \multirow{3}{*}{ Factor } & \multicolumn{2}{|c|}{$\begin{array}{c}\mathrm{Na}(\mathrm{meq} / 100 \mathrm{~g} \\
\text { beet) }\end{array}$} & \multicolumn{2}{|c|}{$\mathrm{K}$ (meq/100g beet) } & \multicolumn{2}{|c|}{$\begin{array}{l}\alpha-N(m e q / 100 g \\
\text { beet) }\end{array}$} \\
\hline & \multicolumn{6}{|c|}{ seasons } \\
\hline & $2013 / 14$ & $2014 / 15$ & $2013 / 14$ & $2014 / 15$ & $2013 / 14$ & $2014 / 15$ \\
\hline \multicolumn{7}{|c|}{ Sowing date $(\mathrm{S})$ : } \\
\hline First date & 1.75 & 1.48 & 6.26 & $6.21 b$ & 2.32 & 2.24 \\
\hline $\begin{array}{l}\text { Second } \\
\text { date }\end{array}$ & 1.72 & 1.53 & 6.25 & $6.34 a$ & 2.36 & 2.35 \\
\hline F- test & NS & NS & NS & ** & NS & NS \\
\hline \multicolumn{7}{|c|}{$\mathrm{N}$-Fertilizer rate (kg N/fad.) $(\mathrm{N})$ : } \\
\hline 80 & $1.48 \mathrm{c}$ & $1.33 c$ & $6.01 \mathrm{c}$ & $5.99 c$ & $1.51 \mathrm{c}$ & $1.48 \mathrm{c}$ \\
\hline 90 & $1.60 \mathrm{~b}$ & $1.50 \mathrm{~b}$ & $6.25 b$ & $6.31 b$ & $2.22 b$ & $2.28 \mathrm{~b}$ \\
\hline 100 & $2.13 a$ & $1.69 a$ & $6.50 \mathrm{a}$ & $6.51 \mathrm{a}$ & $3.30 a$ & $3.13 a$ \\
\hline F- test & ** & ** & $* *$ & ** & ** & ** \\
\hline \multicolumn{7}{|c|}{ Foliar app. of Calcium $(2 \mathrm{~g} / \mathrm{l})(\mathrm{F})$ : } \\
\hline 0 & $1.67 b$ & $1.44 \mathrm{~b}$ & $6.17 \mathrm{~b}$ & $6.20 \mathrm{~b}$ & $2.15 b$ & $2.13 b$ \\
\hline 2 & $1.80 \mathrm{a}$ & $1.56 a$ & $6.34 a$ & $6.34 a$ & $2.53 a$ & $2.46 a$ \\
\hline F- test & $* *$ & ** & $* *$ & $* *$ & ** & ** \\
\hline \multicolumn{7}{|c|}{ Interaction: } \\
\hline $\mathrm{S} \times \mathrm{N}$ & NS & NS & $* *$ & NS & NS & NS \\
\hline $\mathrm{S} \times \mathrm{F}$ & ** & NS & ** & NS & NS & NS \\
\hline $\mathrm{N} \times \mathrm{F}$ & $\star \star$ & NS & ** & NS & NS & $\star \star$ \\
\hline $\mathrm{S} \times \mathrm{N} \times \mathrm{F}$ & ** & NS & NS & NS & $\star \star$ & NS \\
\hline
\end{tabular}

* and N.S indicated $\mathrm{P}<0.05$ and not significant, respectively. Means within the same column for each factor designed by the same letter are not significantly different at $5 \%$ level according to Duncan's multiple range test.

Concerning the effect of nitrogen fertilizer levels on impurities $(\mathrm{Na}, \mathrm{K}$ and $\alpha$ amino $\mathrm{N}$ ) highly significant differences were observed between values of impurities in both seasons Table (4).

Application high nitrogen rate $100 \mathrm{~kg} \mathrm{~N} / \mathrm{fad}$. led to significant increase in all impurities values in both seasons, which caused a bad effect in sugar beet quality. These observations were found by Nemeat Alla (2009) and Sharaf (2012).

As for effect of calcium application as foliar spray on sugar beet, data in Table (4) clear that application of calcium as foliar spraying at $2 \mathrm{~g} / \mathrm{l}$ significantly increased impurities values in both seasons.

No significant interaction effects were found among the three factors under study on most impurities characters in both seasons. Whereas, some significant effects were found in one season in some characters without other.

The interaction effect between the three studied factors on impurities were not significant in both seasons except on $\mathrm{K}$ resulted 
from ( sowing date $\times \mathrm{N}$ levels) in both seasons and on $\mathrm{Na}$ between $(\mathrm{N}$ levels $\times$ foliar spraying calcium ) and between the three factors $(\mathrm{S} \times \mathrm{N}$ $\times \mathrm{F}$ ) on $\mathrm{Na}$ and $\mathrm{K}$ in the first season only, Table (4).

\section{Alkaline coefficient, purity\% and sugar \%:}

Results in Table (5) pointed out that sowing date significantly affected alkaline coefficient in the first season as well as purity \% and sugar\% in the second season only. In respect to influence of nitrogen fertilizer levels $(80,90$ and $100 \mathrm{~kg} \mathrm{~N} / \mathrm{fad}$.), obtained results showed that significant difference were found between mean values of alkaline coefficient. Purity \% and sucrose \% in both seasons. Increasing nitrogen level from 80 to $100 \mathrm{~kg} \mathrm{~N} / \mathrm{fad}$ significantly decreased all values of alkaline coefficient, purity\% and sucrose $\%$ in the two seasons. It could be noticed that alkaline coefficient values must be not decreased than 1.8 because if its values decrease than 1.8 this indicator to there is depletion in amount of nitrogen application, which produced bad quality of sugar beet roots by having $\alpha$ - amino $\mathrm{N}$ with huge amount, which prevent sucrose from crystallization and reduce sugar extractable in the final.

Table (5): Alkaline coefficient, purity $\%$ and sugar percentage as affected by sowing date, nitrogen rate and foliar application of calcium in 2013/2014 and 2014/2015 seasons

\begin{tabular}{|c|c|c|c|c|c|c|}
\hline \multirow{3}{*}{ Factor } & Alkaline & efficient & & & Sugar $p$ & centage \\
\hline & \multicolumn{6}{|c|}{ seasons } \\
\hline & $2013 / 14$ & $2014 / 15$ & $2013 / 14$ & $2014 / 15$ & $2013 / 14$ & $2014 / 15$ \\
\hline \multicolumn{7}{|c|}{ Sowing date $(S)$ : } \\
\hline First date & $3.77 a$ & 3.74 & 92.04 & $92.63 a$ & 20.30 & $21.12 \mathrm{a}$ \\
\hline $\begin{array}{l}\text { Second } \\
\text { date }\end{array}$ & $2.72 b$ & 3.65 & 92.09 & $92.22 \mathrm{~b}$ & 20.38 & $20.53 b$ \\
\hline F- test & * & NS & NS & ** & NS & ** \\
\hline \multicolumn{7}{|c|}{$\mathrm{N}$ - Fertilizer rate (kg N/fad.) (N): } \\
\hline 80 & $5.04 a$ & $4.98 \mathrm{a}$ & $93.33 a$ & $93.51 \mathrm{a}$ & $21.31 \mathrm{a}$ & $21.50 \mathrm{a}$ \\
\hline 90 & $3.56 \mathrm{~b}$ & $3.48 b$ & $92.30 \mathrm{~b}$ & $92.45 b$ & $20.37 b$ & $20.85 b$ \\
\hline 100 & $2.63 \mathrm{c}$ & $2.63 \mathrm{c}$ & $90.56 c$ & $91.32 \mathrm{c}$ & $19.35 c$ & $20.14 \mathrm{c}$ \\
\hline F- test & ** & ** & ** & ** & ** & ** \\
\hline \multicolumn{7}{|c|}{ Foliar app. of calcium $(2 \mathrm{~g} / \mathrm{l})(\mathrm{F})$ : } \\
\hline 0 & $4.03 a$ & $3.93 a$ & $92.37 a$ & $92.69 a$ & $20.52 a$ & $21.00 \mathrm{a}$ \\
\hline 2 & $3.46 \mathrm{~b}$ & $3.46 \mathrm{~b}$ & $91.76 \mathrm{~b}$ & $92.17 \mathrm{~b}$ & $20.16 \mathrm{~b}$ & $20.66 \mathrm{~b}$ \\
\hline F- test & ** & ** & ** & ** & ** & ** \\
\hline \multicolumn{7}{|c|}{ Interaction: } \\
\hline $\mathrm{S} \times \mathrm{N}$ & $\overline{N S}$ & NS & NS & * & ** & ** \\
\hline$S \times F$ & * & NS & NS & NS & NS & NS \\
\hline $\mathrm{N} \times \mathrm{F}$ & 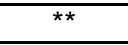 & ** & ** & NS & NS & NS \\
\hline $\mathrm{S} \times \mathrm{N} \times \mathrm{F}$ & ** & NS & NS & NS & NS & NS \\
\hline
\end{tabular}


* and N.S indicated $\mathrm{P}<0.05$ and not significant, respectively. Means within the same column for each factor designed by the same letter are not significantly different at $5 \%$ level according to Duncan's multiple range test.

Similar findings were found by Leilah et al. (2005) and Sharaf (2102). Concerning to effect of foliar spraying with calcium to sugar beet plants, data in Table (5) show that addition of calcium at rate of $2 \mathrm{~g} / \mathrm{l}$. as foliar spray exhibited significant decrease in the three characters in both season. These results are in harmony with Artyszak et al. (2014).

The interaction between $\mathrm{N}$ level and foliar application of calcium significantly affected by alkaline coefficient in both seasons as shown in Table (5-a1). The highest values of alkaline coefficient was recorded when sugar beet plants fertilized with $80 \mathrm{~kg} \mathrm{~N} / \mathrm{fad}$ and sprayed with distilled water (control) in the two seasons.

Table (5-a1): Alkaline coefficient as affected by the interaction between $\mathrm{N}$ level and foliar application of calcium in 2013/2014 and 2014/2015 seasons

\begin{tabular}{|c|c|c|c|}
\hline \multirow{2}{*}{ Foliar app. of calcium $(2 \mathrm{~g} / \mathrm{l})$} & \multicolumn{3}{|c|}{$\mathrm{N}$ - rate $(\mathrm{kg} \mathrm{N} /$ fad.) } \\
\hline & 80 & 90 & 100 \\
\hline \multicolumn{4}{|c|}{$2013 / 2014$} \\
\hline 0 & $5.54 \mathrm{a}$ & $3.83 \mathrm{c}$ & $2.72 \mathrm{e}$ \\
\hline 2 & $4.55 b$ & $3.30 \mathrm{~d}$ & $2.54 \mathrm{e}$ \\
\hline \multicolumn{4}{|c|}{$2014 / 2015$} \\
\hline 0 & $5.32 a$ & $3.79 c$ & $2.69 \mathrm{e}$ \\
\hline 2 & $4.65 \mathrm{~b}$ & $3.16 d$ & $2.57 \mathrm{e}$ \\
\hline
\end{tabular}

Means designed by the same letter are not significantly different at $5 \%$ level, using Duncan's multiple range test.

The interaction between sowing datex nitrogen rate resulted in a significant effect on sugar percentage in both seasons, Table (5-a2). The highest values of sucrose\% were obtained from early sowing and in the two season $80 \mathrm{~kg} \mathrm{~N} / \mathrm{fad}$.

Table (5-a2): Sucrose \% as affected by the interaction between sowing date and nitrogen rate in 2013/2014 and 2014/2015 seasons

\begin{tabular}{|c|c|c|c|}
\hline \multirow{4}{*}{ Sowing date } & \multicolumn{3}{|c|}{ N- rate $(\mathrm{kg} \mathrm{N} / \mathrm{fad})}$. \\
\cline { 2 - 4 } & 80 & 90 & 100 \\
\hline First date & $21.42 \mathrm{a}$ & $20.17 \mathrm{~d}$ & $19.31 \mathrm{e}$ \\
\hline Second date & $21.20 \mathrm{~b}$ & $20.56 \mathrm{c}$ & $19.39 \mathrm{e}$ \\
\hline \multicolumn{5}{|c|}{$2014 / 2015$} \\
\hline First date & $21.73 \mathrm{a}$ & $21.27 \mathrm{~b}$ & $20.37 \mathrm{c}$ \\
\hline Second date & $21.27 \mathrm{~b}$ & $20.42 \mathrm{c}$ & $19.91 \mathrm{~d}$ \\
\hline
\end{tabular}

Means designed by the same letter are not significantly different at $5 \%$ level, using Duncan's multiple range test. 


\section{Extractable Sugar, extractability and sugar losses percentages:}

Sowing date exhibited significant differences in extractable sugar, extractability and sugar losses\% only in the seconded season, Table (6). The first sowing date recorded the highest values of sugar extractable and extractability \%, while the second sowing date gave the highest values of sugar losses\%. Similar results were obtained by Nemeat Alla (2009) and Sharaf (2012).

Increasing N-level up to $100 \mathrm{~kg} \mathrm{~N} /$ fad. significantly decreased extractable sugar and extractability \%, while it significantly increased sugar losses\% in both seasons, Table (6). These results may be due to bad effect for over fertilization with nitrogen which caused on increase in root content from nitrogen, which resulted in losses of sugar in molasses during industrial stage in Factories. These results are agreement with those obtained by Abou Shady et al. (2011) and Sharaf (2012). Foliar application of calcium at the rate of $2 \mathrm{~g} / \mathrm{l}$ resulted in a significant reduction in extractable sugar and extractability \%, while it increased sugar losses\% in the two seasons of study, Table (6).Nemeat Alla (2009) came to the same results.

Table (6): Extractable sugar\%, Extractability\%, sugar losses\% and Total soluble solids\% as affected by sowing date, nitrogen rate and foliar application of calcium in 2013/2014 and 2014/2015 seasons

\begin{tabular}{|c|c|c|c|c|c|c|c|c|}
\hline \multirow{3}{*}{ factor } & \multicolumn{2}{|c|}{$\begin{array}{c}\text { Extractable } \\
\text { sugar\% }\end{array}$} & \multicolumn{2}{|c|}{ Extractability\% } & \multicolumn{2}{|c|}{ sugar losses $\%$} & \multicolumn{2}{|c|}{ TSS $\%$} \\
\hline & \multicolumn{8}{|c|}{ seasons } \\
\hline & $2013 / 14$ & $2014 / 15$ & $2013 / 14$ & $2014 / 15$ & $2013 / 14$ & $2014 / 15$ & $2013 / 14$ & $2014 / 15$ \\
\hline \multicolumn{9}{|c|}{ Sowing date (S): } \\
\hline $\begin{array}{l}\text { First } \\
\text { date }\end{array}$ & 17.50 & $18.39 a$ & 86.11 & $87.01 \mathrm{a}$ & 2.20 & $2.13 b$ & $22.00 \mathrm{a}$ & $21.95 a$ \\
\hline $\begin{array}{l}\text { Second } \\
\text { date }\end{array}$ & 17.58 & $17.74 b$ & 86.16 & $86.37 \mathrm{~b}$ & 2.21 & $2.19 a$ & $21.19 b$ & $20.43 b$ \\
\hline F-test & NS & ** & NS & ** & NS & * & ** & ** \\
\hline \multicolumn{9}{|c|}{$\mathrm{N}$-fertilizer rate (kg N /fad.) (N): } \\
\hline 80 & $18.78 a$ & $19.00 a$ & $88.14 a$ & $88.39 a$ & $1.92 \mathrm{c}$ & $1.90 \mathrm{c}$ & $22.72 a$ & $21.81 \mathrm{a}$ \\
\hline 90 & $17.61 \mathrm{~b}$ & $18.08 \mathrm{~b}$ & $86.47 \mathrm{~b}$ & $86.73 b$ & $2.15 b$ & $2.16 \mathrm{~b}$ & $21.85 b$ & $21.21 \mathrm{~b}$ \\
\hline 100 & $16.22 \mathrm{c}$ & $17.11 \mathrm{c}$ & $83.80 \mathrm{c}$ & $84.94 c$ & $2.53 a$ & $2.43 a$ & $20.32 c$ & $20.55 c$ \\
\hline F-test & $\star \star *$ & ** & ** & ** & ** & ** & ** & ** \\
\hline \multicolumn{9}{|c|}{ Foliar app. of calcium( $2 \mathrm{~g} / \mathrm{l})(\mathrm{F})$ : } \\
\hline 0 & $17.79 a$ & $18.30 a$ & $86.60 a$ & $87.08 \mathrm{a}$ & $2.13 b$ & $2.10 \mathrm{~b}$ & $21.96 a$ & $21.37 a$ \\
\hline 2 & $17.29 b$ & $17.83 b$ & $85.67 \mathrm{~b}$ & $86.29 \mathrm{~b}$ & $2.27 a$ & $2.22 a$ & $21.53 b$ & $21.00 \mathrm{~b}$ \\
\hline F-test & *夫 & ** & $\star \star$ & ** & ** & ** & ** & ** \\
\hline \multicolumn{9}{|c|}{ Interaction: } \\
\hline $\mathrm{S} \times \mathrm{N}$ & * & ** & * & * & NS & NS & NS & NS \\
\hline$S \times F$ & NS & NS & NS & NS & NS & NS & * & NS \\
\hline $\mathrm{N} \times \mathrm{F}$ & * & NS & ** & NS & ** & NS & ** & ** \\
\hline $\begin{array}{c}\mathrm{S} \times \mathrm{N} \times \\
\mathrm{F}\end{array}$ & NS & NS & NS & NS & * & NS & ** & ** \\
\hline
\end{tabular}


* and N.S indicated $\mathrm{P}<0.05$ and not significant, respectively. Means within the same column for each factor designed by the same letter are not significantly different at $5 \%$ level according to Duncan's multiple range test.

The interaction between sowing date $\times$ nitrogen level Significantly affected extractable sugar in both seasons, Maximum values extractable sugar\% (18.90 and $19.26 \%)$ were obtained from early sowing date application of nitrogen fertilizer ate rate of $80 \mathrm{~kg}$ $\mathrm{N} / \mathrm{fad}$. in the first and second seasons, respectively as shown in Table (6-a1).

Table (6-a1): Extractable sugar \% as affected by the interaction between sowing date and nitrogen rate in 2013/2014 and 2014/2015 seasons

\begin{tabular}{|c|c|c|c|}
\hline \multirow{2}{*}{ Sowing date } & \multicolumn{3}{|c|}{ N-rate $(\mathrm{kg} \mathrm{N} / \mathrm{fad})}$. \\
\cline { 2 - 4 } & 80 & 90 & 100 \\
\hline \multicolumn{5}{|c|}{$2013 / 2014$} \\
\hline First date & $18.90 \mathrm{a}$ & $17.42 \mathrm{~d}$ & $16.18 \mathrm{e}$ \\
\hline Second date & $18.66 \mathrm{~b}$ & $17.81 \mathrm{c}$ & $16.26 \mathrm{e}$ \\
\hline \multicolumn{5}{|c|}{$2014 / 2015$} \\
\hline First date & $19.26 \mathrm{a}$ & $18.54 \mathrm{c}$ & $17.37 \mathrm{e}$ \\
\hline Second date & $18.76 \mathrm{~b}$ & $17.62 \mathrm{~d}$ & $16.85 \mathrm{f}$ \\
\hline
\end{tabular}

Means designed by the same letter are not significantly different at $5 \%$ level, using Duncan's multiple range test.

Significant interaction effects between sowing date $\times$ nitrogen level on extractability \% were found in both seasons as shown in Table (6). The highest values of extractability \% were observed when sugar beet plants received $80 \mathrm{~kg} \mathrm{~N} / \mathrm{fad}$ under early sowing date, Table (6-a2)

Table (6-a2): Extractability \% as affected by the interaction between sowing date and nitrogen rate in 2013/2014 and 2014/2015 seasons

\begin{tabular}{|c|c|c|c|}
\hline \multirow{2}{*}{ Sowing date } & \multicolumn{3}{|c|}{$\mathrm{N}$ - rate $(\mathrm{kg} \mathrm{N} / \mathrm{fad})}$. \\
\cline { 2 - 4 } & 80 & 90 & 100 \\
\hline \multicolumn{5}{|c|}{$2013 / 2014$} \\
\hline First date & $88.22 \mathrm{a}$ & $86.60 \mathrm{c}$ & $83.84 \mathrm{e}$ \\
\hline Second date & $88.06 \mathrm{~b}$ & $86.35 \mathrm{~d}$ & $83.77 \mathrm{f}$ \\
\hline \multicolumn{5}{|c|}{$2014 / 2015$} \\
\hline First date & $88.58 \mathrm{a}$ & $87.18 \mathrm{c}$ & $85.28 \mathrm{e}$ \\
\hline Second date & $88.19 \mathrm{~b}$ & $86.29 \mathrm{~d}$ & $84.69 \mathrm{f}$ \\
\hline
\end{tabular}

Means designed by the same letter are not significantly different at $5 \%$ level, using Duncan's multiple range test.

\section{Total soluble solids (T.S.S).}

Average of total soluble solids in term (T.S.S) as affected by planting date, nitrogen level and foliar spraying with calcium and their interaction effects in the two growing seasons 2013/2014 and 2014/2015 are presented in Table (6). 
Sowing date had a significant effect on (T.S.S) in both seasons. Early sowing date significantly increased T.S.S\%. Nemeat Alla et al. (2007) found similar results.

Data presented in Table (6) show that there were highly significant differences in obtained (T.S.S) in both growing seasons. The highest T.S.S. values (22.72 and $21.81 \%$ ) by $80 \mathrm{~kg} \mathrm{~N} / \mathrm{fad}$. compared to the lowest (T.S.S) values which resulted from addition $100 \mathrm{~kg} \mathrm{~N} / \mathrm{fad}$. (20.23 and $20.55 \%$ )in two seasons of study,. This was fairly true in both seasons these results were obtained by Nemeat Alla et al. (2007) and Gomaa et al. (2013).

Application of calcium at the rate of $2 \mathrm{~g} / \mathrm{l}$ as foliar spray exhibited significant reduction in T.S.S as compared to control treatment and gave the lowest T.S.S (21.23 and $21.00 \%)$ in the first and second seasons, respectively. Similar results were stated by Nemeat Alla (2009).

Significant interaction effects on T.S.S. were found between Nrate $\times$ foliar applications of calcium in both seasons, Table (6). Maximum values of T.S.S. were obtained with $80 \mathrm{~kg} \mathrm{~N} / \mathrm{fad}$. $\times$ Control (spraying sugar beet plants with distilled water), Table (6-a3).

The interaction among the three factors under study significantly affected by T.S.S. \% in both seasons as shown in Table (6). Data present in Table (6-a4) show clearly that sowing sugar beet on early sowing date with $80 \mathrm{~kg} \mathrm{~N} / \mathrm{fad}$. under foliar spraying with distilled water ( control treatment) recorded the highest T.S.S. in the two seasons.

Table (6-a3): T.S.S. \% as affected by the interaction between $\mathrm{N}$-rate and foliar application of calcium in 2013/2014 and 2014/2015seasons

\begin{tabular}{|c|c|c|c|}
\hline \multirow{2}{*}{$\begin{array}{l}\text { Foliar pp. of calcium } \\
(2 \mathrm{~g} / \mathrm{l})\end{array}$} & \multicolumn{3}{|c|}{$\mathrm{N}$ - rate ( $\mathrm{kg} \mathrm{N} /$ fad.) } \\
\hline & 80 & 90 & 100 \\
\hline \multicolumn{4}{|c|}{$2013 / 2014$} \\
\hline 0 & $22.83 a$ & $22.29 \mathrm{c}$ & $20.77 \mathrm{e}$ \\
\hline 2 & $22.60 \mathrm{~b}$ & $21.42 \mathrm{~d}$ & $19.68 \mathrm{f}$ \\
\hline \multicolumn{4}{|c|}{$2014 / 2015$} \\
\hline 0 & $22.06 \mathrm{a}$ & $21.28 \mathrm{c}$ & $20.79 \mathrm{e}$ \\
\hline 2 & $21.57 \mathrm{~b}$ & $12.14 \mathrm{~d}$ & $20.32 f$ \\
\hline
\end{tabular}

Means designed by the same letter are not significantly different at $5 \%$ level, using Duncan's multiple range test. 
Table (6-a4): T.S.S. \% as affected by the interaction among sowing date, Nrate and foliar application of calcium in 2103/2014 and 2014/2015 seasons

\begin{tabular}{|c|c|c|c|c|}
\hline \multirow{2}{*}{ Sowing date } & \multirow{2}{*}{$\begin{array}{c}\text { Foliar of } \\
\text { calcium }(2 \mathrm{~g} / \mathrm{l})\end{array}$} & \multicolumn{3}{|c|}{$\mathrm{N}$-rate (kg N / fad.) } \\
\hline & & 80 & 90 & 100 \\
\hline \multicolumn{5}{|c|}{$2013 / 2014$} \\
\hline \multirow{2}{*}{ First date } & 0 & $23.24 a$ & $22.79 \mathrm{~b}$ & $21.30 f$ \\
\hline & 2 & $23.08 a$ & $21.80 \mathrm{e}$ & $19.82 \mathrm{i}$ \\
\hline \multirow{2}{*}{ Second date } & 0 & $22.42 \mathrm{c}$ & $21.80 \mathrm{e}$ & $20.24 \mathrm{~h}$ \\
\hline & 2 & $22.12 d$ & $21.03 \mathrm{~g}$ & $19.54 \mathrm{j}$ \\
\hline \multicolumn{5}{|c|}{$2014 / 2015$} \\
\hline \multirow{2}{*}{ First date } & 0 & $22.69 a$ & $22.06 \mathrm{c}$ & $21.73 d$ \\
\hline & 2 & $22.23 b$ & $22.00 \mathrm{c}$ & $21.01 \mathrm{f}$ \\
\hline \multirow{2}{*}{ Second date } & 0 & $21.42 \mathrm{e}$ & $20.50 \mathrm{~g}$ & $19.84 \mathrm{i}$ \\
\hline & 2 & $20.01 f$ & $20.27 \mathrm{~h}$ & $19.63 j$ \\
\hline
\end{tabular}

Means designed by the same letter are not significantly different at $5 \%$ level, using Duncan's multiple range test.

\section{REFERENCE}

Abd EL-Hadi, A.H.; A.M.A. Aly; A.A. Attiat; M.A. Zidan and F. Zahran (2002). Response of sugar beet to variousnforms and rates of nitrogen fertilizer. Egyption J. Soil. Sci., 42(4): 643-658.

Abou Shady, Kh.A.; S.S. Zalat and M.F.M. Ibraheim (2011). Influence of of use nitrogen fertilizer levels and sources for late sowing date on yield and quality of sugar beet (Beta Vulgaris L.) in North Nile delta. J. plant production, Mansoura Univ., 2(3):425-436.

Artyszak, A.; D. Gozdowski and K. Kucinska (2014). The effect of foliar fertilization with marine calcite in sugar beet. Plant soil Environ. 60(9): 413-417.

Basal, S.A.A.; A.A. Zohry and K.A. EL-Douby (2001). Effect of row and hill spacing and bio-mineral $\mathrm{N}$-fertilization rates on sugar beet productivity. J. Agric. Sci. Mansoura Univ., 26 (8): 5217-5226.

Biaczyk, p.; (2005). Effect of fertilization calcium concentration, its uptake and sugar beet productivity. J. of Element logy, 10(10): 8598.

Brown, J.D. and O. Lilliand (1964). Rapid determination of Potassium, Sodium in Plant material and soil extraction by flam photometry by proc. Amer. Soci. Hort. Soci 48: 340-364.

Carruthers, A.; J.F.T. Oldfield and H.J. Teague (1962). Assessment of beet quality. Paper presented to the $15^{\text {th }}$ Annual Technical Conf., British Sugar Corporation, 8 pp.

Devillers, P. (1988). Prevision du sucre melasse sucrerie feanases 190200. (C.F. The Sugar Beet Crop. Book).

Dexter, S.T.; M.G. Frankes and F.W. Snyder (1976). A rapid and practical method of determining extractable white sugar as may be applied to the evaluation of agronomic practices and grower deliveries in 
the sugar beet industry. J. Am., soc., sugar beet Technol. 14:433454.

Duncan, B.D. (1955). Multiple range and multiple F. test Biometric 11:142.

EL-Kassaby, A.T. and A.A. Leilah (1992). Influence of plant density and nitrogen fertilizer levels on sugar beet productivity proc. $5^{\text {th }}$ Conf. Agron. Zagazig. 13-15 Sep. 2: 954-962.

EL-Sarag, Eman I. and S.H. Moselhy (2013). Response of suagr beet quantity and quality to nitrogen and potassium fertilization under sandy soils conditions. Asian journal of Crop Sciences 5: 295-303.

Gomaa, M.A.; F.I. Radan; A. EL-Gharabawy and N.K. EL-Safy (2013). Effect of mineral and Bio nitrogen fertilization leaf defoliation rates and times of defoliation on yield and quality of sugar beet. J. Adv Agric. Res. (Fac. Agric Saba Basha) Vol. 18 (4): 850-859.

Gomes, K.A. and A.A. Gomes (1984). Statistical procedures for agricultural research. An. International Rice research institute Book John Willey and Sons. Inc., New York.

Hanna, A.S.; A.T. El-Kassaby; A.N. Attia and M.A. Badawi (1988). Studies on the inter-relationships among planting dates, hill spacing's varieties and nitrogen fertilization in sugar beet (Beta vulgaris L.) J. Agric. Sci. Mansoura Univ., 13 (2): 598-605.

Ismail, A.M.A. and R.A.A. EL-Ghait (2005). Effect of nitrogen sources and levels on yield and quality of sugar beet. Egypt J. Agric. Res. 83 (1): 229-239.

Kandil, A.A.; M.A. Badawi; S.A. EL-Moursy and U.M.A. Abdou(2002). Effect of planting dates, nitrogen levels and bio- fertilization treatment on: 1- Growth attributes sugar beet (Beta vulgaris L.) J. Agric. Sci., Mansoura Univ., 27 (11):7247-7255.

Le-Doct, A. (1927). Commercial determination of sugar beet root using the saches - Le-Doct process int. Sug. J., 29:488-492. (C.F. suagr beet Nutrition, 1927. Appl. Sci. Pub. Ltp. London, P. Drycott).

Leilah, A.A.; M.A. Badawi; E.M. Said; M.H. Ghonema and M.A.E. Abdou (2005). Effect of planting dates, plant population and nitrogen fertilization on sugar beet productivity under the newly keclaimed sandy soils in Egypt. Sci. J. of King Faisal Uni., 6(1):95-110.

Mahmoud, E.A.; M.A. EL-Metwally and M.E.M. Gobary (1999). Yield and quality of sown multigerm sugar beet as affected by plant densities and nitrogen levels. J. Agric. Sci. Mansoura Univ., 24 (9): 499-516.

Mc Ginnus, R.A. (1971). Sugar beet technology $2^{\text {nd }}$ ed. Sugar beet development foundation, fat., Calins Colo, USA.

Nemeat Alla, E.A.E.; K.A. Abou Shady and N.O. Yousef (2007). Sugar beet yield and quality as affected by sowing patterns and nitroden levels. J. Agric. Sci. Mansoura Univ., 32(10): 8069-8078.

Nemeat Alla, H.E.A. (2009). Effect of nitrogen, calcium and boron fertilization on productivity and quality of sugar beet under different planting patterns. Ph.D. Fac. Of Agric. Kafer EL-Sheik Univ. Egypt. 
Nemeat Alla, H.E.A.; A.M. Hamad and S.S. Zalat (2014). Productivity and quality of sugar beet as affected by nitrogen, potassium and boron fertilizers. J. Agric. Res. Kafer EL-Sheik Univ., 40 (3):553-570.

Refay, Y.A. (2010). Root yield and quality traits of three sugar beet (Beta Vulgaris $L$.) varieties in relation to sowing date and stand densities. World J. of Agro. Sci. 6(5): 589-594.

Sadre, p.; A. Soleymain and H.R. Javanmard (2012). Root yield and quality traits of sugar beet ( Beta vulgaris L.) in relation to nitrogen fertilizer and plant density in Isfahan region.intl. J. Agri. Crop Sci. Vol., 4920), 1504-1507.

Salim Fawkia M., A.H. Belal, M.S. Atta, R.M. Hefny and I.H.M. ELGeddawy (2012). Effect of planting patterns, nitrogen levels and boron application on yield, yield components and quality of Sugar Beet (Beta vulgaris L.) Agricural research Journal suez Canal Univ., Volum.12(2):17-25.

Sharaf, E.A.A.M. (2012). Effect of some agricultural and biological treatments on sugar beet production. Ph. D. Fac. of. Assiut., Egypt.

Srivastava, S.N.L. and C. Singh (1981). Effect of sowing and harvesting dates on yield and quality of sugar beet. Indian J. Agron: 26. 377381.

$$
\text { الملخص العربي }
$$

تأثر محصول وجودة بنجر السكر بمواعيد الزراعة والتسميد التيتروجيني وكذلك التك

$$
\text { الرش بالكالسيوم اعبر ألرئ }
$$

$$
\text { معهز بحوث المحاصيل السكرية السيّ أحمد نعرث البحوث الله الزراعية ــ الجيزة }
$$

اقيمت تجربتان حقليتان في المزرعة البحثية لمحطة بحوث سخا الزراعية بكفر

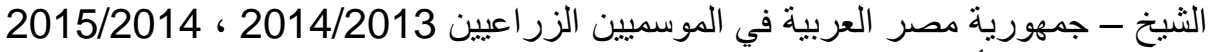

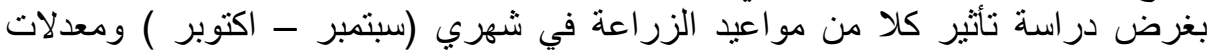

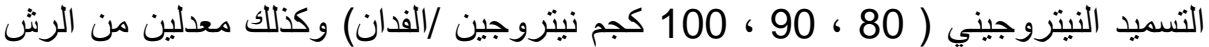

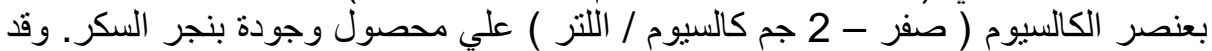

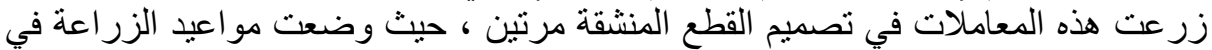

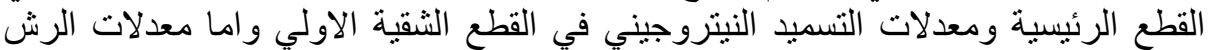

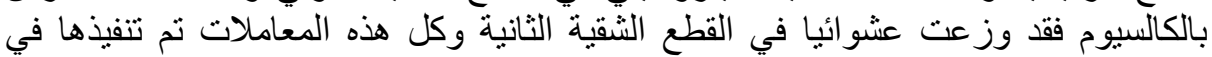

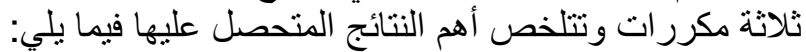

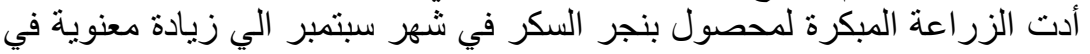

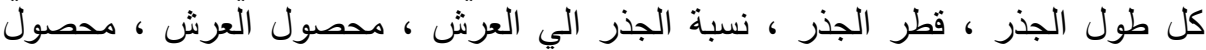

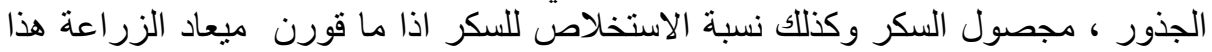

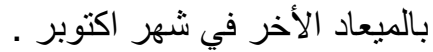




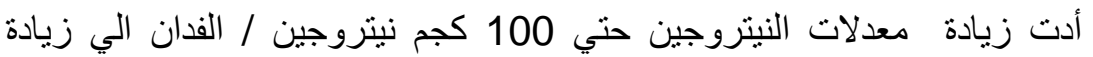

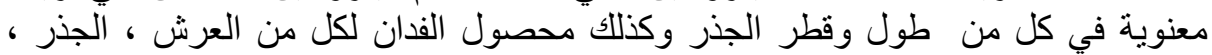

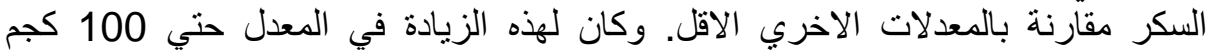

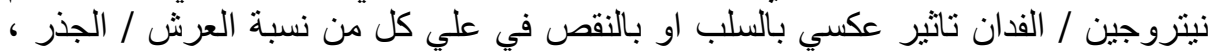

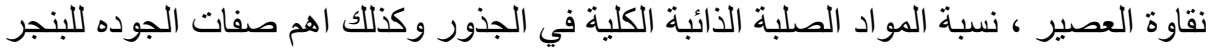
و هي نسبة السكروز في الجذر.

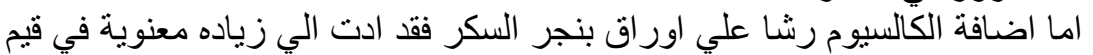

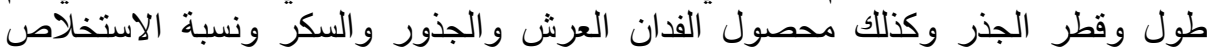

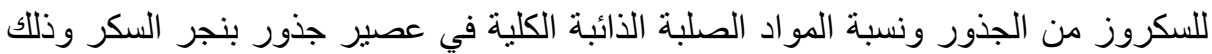

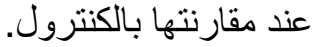

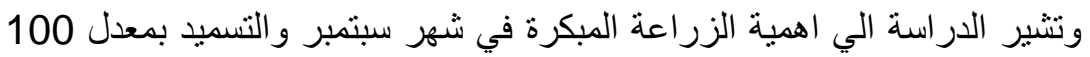

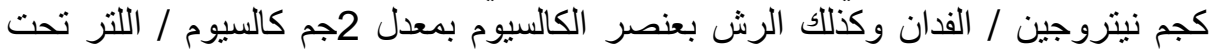
ظروف هذا البحث الذي اجري في محافظة كفر الثيخ. 